\title{
A AVENIDA NEVSKI EM MEMÓRIAS DO SUBSOLO, DE DOSTOIEVSKI: A RUA COMO PALCO DAS CONTRADIÇÕES DA MODERNIDADE
}

\author{
Katia Luisa Seckler*
}

\begin{abstract}
RESUMO: As ruas são tidas como espaços tipicamente modernos. Com as novas configurações que assume na modernidade, a rua torna-se um lugar onde as pessoas vão para 'ver e ser vistas' pelas outras: a rua deixa de ser apenas um local de trânsito e passa a ser um lugar de relacionamentos sociais. É nesta época que surgem os grandes bulevares, as avenidas com lojas e cafés. Tais mudanças causam a o mesmo tempo fascínio e desconfiança, sentimentos presentes na obra de muitos escritores modernos. Assim, o objetivo deste trabalho é analisar a função da Avenida Nevski, principal rua de São Petersburgo, no romance Memórias do subsolo, de Dostoievski, levando em consideração a relação entre espaço e personagem nesta obra.
\end{abstract}

PALAVRAS-CHAVE: Sujeito moderno - Espaço urbano - Avenida Nevski

ABSTRACT: The streets are considered as typically modern spaces. Due to the different characteristics that the street assumes in Modernity, it becomes a place where people go to meet each other, besides, it is no longer a place just for traffic, it is a place for social relationships. In modern period arise the great boulevards, the avenues with shops and coffee houses, and the public illumination increases. These changes cause, simultaneously, fascination and suspicion, feelings that are present in the works of many modern writers. Thus, the objective of this work is to analyze the function of Nevski Avenue, Saint Petersburg's main street, in Dostoievski's novel Memórias do subsolo (Notes from the underground), considering the relation between space and character.

KEYWORDS: Modern subject - Urban space - Nevski Avenue

\section{INTRODUÇÃO}

Fiodor Dostoievski é um dos mais influentes escritores da literatura ocidental. Sua obra, ampla e significativa, serviu como fonte de temas que se tornaram recorrentes na produção literária moderna. Como atesta Bradbury (1990, p. 44), "de todos os romancistas do século XIX, Dostoievski foi o que mais influenciou a literatura moderna, mas ele também representava algo de extremo no espírito moderno". Este extremismo adviria das próprias lutas e contradições que se travavam no interior dos sujeitos modernos, entre vontade e consciência, intelecto e sentimento. Mas provinha também do contexto social russo, dividido entre a antiga ordem das coisas, aparentemente imutável, e as violentas irrupções do novo a exigir o seu direito de expressão.

O protagonista de Memórias do Subsolo situa-se nesta atmosfera conflitante. Definido como "paradoxalista", isto é, um homem sempre em contradição, que investe

\footnotetext{
* Mestre em Estudos Literários pela Universidade Federal de Santa Maria (UFSM). E-mail: katiaseckler@hotmail.com.
} 
contra tudo e contra todos, mas principalmente contra sua própria consciência, vive em constante embate entre as suas idéias e as diferentes ideologias em voga na época em que vive (os anos de 1860), especialmente o racionalismo e a fé no progresso. Sobre este tema, desenvolvido na primeira parte do livro, vários textos de crítica literária e debates filosóficos já foram produzidos - muitos o consideram como uma prefiguração das ideias de Freud sobre o inconsciente e outros encontram aí os fundamentos da filosofia de Nietszche (SCHNAIDERMAN, 2000). Joseph Frank (2002) relata que a primeira parte de Memórias do Subsolo, intitulada "O subsolo", chegou a ser reproduzida na íntegra em uma antologia de textos filosóficos.

$\mathrm{Na}$ segunda parte da novela, intitulada "A propósito da neve molhada", encontra-se outro paradoxo que se instaura na vida do protagonista: consiste no conflito entre o "subsolo", designação que remete à sua introspecção, sua necessidade de afastarse da civilização, e o desejo de ir para a rua, espaço que, na modernidade, assume um novo e definitivo significado. Neste contexto, o "subsolo" é entendido não apenas como um espaço físico - lugar à margem do grande centro urbano, onde vive a escória da sociedade -, mas como uma metáfora do isolamento e da solidão da personagem.

Nas ruas de São Petersburgo, particularmente na avenida principal, a Avenida Nevski, o protagonista sairá do seu subterrâneo e viverá na prática o confronto com outras pessoas e consigo mesmo, com sua autoimagem medíocre e sua extrema vaidade. A rua tem seu significado na medida em que é o espaço onde o caráter contraditório do protagonista, representado nos devaneios e diatribes da primeira parte, se exterioriza. Neste espaço, são narrados eventos importantes para entender a relação do protagonista, enquanto sujeito na época moderna, com a sociedade em que está inserido. Este trabalho tem como objetivo analisar o personagem "homem do subsolo" e seu comportamento nas ruas de São Petersburgo, bem como verificar qual é a importância da representação da rua no romance Memórias do Subsolo, tendo em vista sua caracterização como espaço típico da modernidade e sua relação com o protagonista.

\title{
A MODERNIDADE E A RUA COMO ESPAÇO TIPICAMENTE MODERNO
}

O conceito de modernidade ainda não encontrou uma definição consensual. Berman (2007, p. 24) define a modernidade como "um tipo de experiência vital, de tempo e espaço, de si mesmo e dos outros, das possibilidades e perigos da vida - que é compartilhada por homens e mulheres em todo o mundo, hoje". Ser moderno, nas palavras deste estudioso, é

\begin{abstract}
encontrar-se em um ambiente que promete aventura, poder, alegria, crescimento, autotransformação e transformação das coisas ao redor - mas ao mesmo tempo ameaça destruir tudo o que temos, tudo o que sabemos, tudo o que somos. [...] ela nos despeja a todos num turbilhão de permanente desintegração e mudança, de luta e contradição, de ambigüidade e angústia (ibid, p. 205).
\end{abstract}

Esse "turbilhão" da vida moderna se deve a vários fatores, dentre eles, as descobertas científicas, que ocasionam a "mudança da nossa imagem do universo e do lugar que ocupamos nele"; a industrialização, que "transforma conhecimento científico em tecnologia, cria novos ambientes humanos", acelera o ritmo da vida e cria novas formas de poder; a explosão demográfica, o vertiginoso crescimento urbano, o 
desenvolvimento dos meios de comunicação de massa, a nova forma de organização dos Estados nacionais, "que lutam com obstinação para expandir seu poder" (BERMAN, 2007, p. 25); o surgimento dos movimentos sociais de massa e de nações, que desafia os governantes; e, finalmente, um mercado capitalista mundial, que dirige e manipula todas as pessoas e instituições, e que se encontra em permanente expansão.

Dentre os elementos que caracterizam a modernidade, pode-se destacar o espaço urbano, que ganha uma nova forma e significado, e a rua, tida como espaço paradigmático da modernidade. A rua deixa de ser apenas um espaço de circulação de veículos e pessoas. Com as novas configurações que assume na modernidade, a rua torna-se um lugar aonde as pessoas vão para "ver e ser vistas"; a rua deixa de ser apenas um local de trânsito e passa a ser um lugar de relacionamentos sociais. Com a modernidade, surgem os grandes bulevares parisienses, as avenidas com atrativas vitrines, lojas e cafés; a evolução na iluminação pública, com os lampiões a gás e, posteriormente, os lampiões elétricos, o que gera a possibilidade de maior movimentação de pessoas à noite. Todas essas mudanças ocasionam uma nova forma de os sujeitos encararem a rua e novas motivações para frequentá-la, mas, ao mesmo tempo, causam fascínio e desconfiança, sentimentos presentes na obra de muitos escritores modernos.

Assim, as ruas se tornaram temas e, de certa forma, personagens de algumas das mais significativas expressões literárias da literatura moderna. No século XIX, produziu-se um número significativo de obras poéticas, romances e contos em que a rua e a cidade aparecem como espaços característicos da modernidade. Berman destaca que Baudelaire foi um dos escritores que mais contribuiu para a compreensão do que é ser um homem moderno, viver na modernidade; uma das ideias mais importantes nos ensaios de Baudelaire é a de que o sentido da modernidade é extremamente vago, de difícil definição. Os pensamentos do poeta francês sobre a modernidade também encontram expressão nos poemas em prosa de Spleen de Paris. Tais poemas revelam a cidade como protagonista da modernidade e as ruas, os bulevares como novos espaços e novas formas de sociabilidade. Baudelaire, na poesia, e Benjamin, em seus ensaios, chamam a atenção para o fato de que a modernidade é contraditória, de que existe uma discrepância entre as possibilidades oferecidas pelo progresso e pela evolução da técnica, e a ausência de um mundo realmente melhor.

A necessidade de modernizar as cidades gerou desenvolvimento e melhorias nas ruas, mas não foi gratuita. Conforme observa Benjamin (1989, p. 84),

[a] cidade de Paris ingressou neste século sob a forma que lhe foi dada por Haussmann. Ele realizou sua transformação da imagem da cidade com os meios mais modestos que se possa pensar: pás, enxadas, alavancas e coisas semelhantes. Que grau de destruição já não provocaram esses instrumentos limitados!

Esta imagem da construção de uma nova Paris tem certa semelhança com a descrição de São Petersburgo feita por Marshall Berman. Na nova capital russa, idealizada por Pedro, o Grande, no início do século, o entusiasmo da modernidade e o anseio por incorporar na Rússia os padrões europeus tiveram um custo muito alto: milhares de servos mortos na construção da cidade. Conforme o autor, "[o]s sacrifícios humanos foram imensos: em três anos, a cidade devorou um exército de cerca de 150 mil trabalhadores - mortos ou arruinados fisicamente - e o Estado, sem cessar, buscou outros no interior" (BERMAN, 2007, p. 209). 
A modernização das cidades, portanto, não foi nada inofensiva. Além de destruição e mortes, ainda possibilitou que a vida nas cidades mostrasse uma face antes escondida: os pobres, os miseráveis, que, em Paris, tiveram suas casas derrubadas e foram atirados às ruas. Em Petersburgo, os funcionários e servos, que, mesmo circulando no mesmo espaço que as pessoas pertencentes a castas mais elevadas, não conquistaram sua dignidade na rua e continuaram, mesmo num espaço público, sendo obrigados a reverenciar a quem estava acima na escala social - situação que será representada ficcionalmente em Memórias do Subsolo e que constitui o centro da análise deste trabalho. Isso demonstra que os fascinantes projetos das ruas no século XIX não apenas revelaram as novidades e atrativos do mundo moderno, mas desvelaram a desigualdade que continuava a existir, mesmo numa sociedade que se acreditava evoluindo nas bases do progresso e da racionalidade.

$\mathrm{Na}$ literatura russa, alguns exemplos de obras que têm como tema a vivência do sujeito moderno nas cidades e nas ruas são: o poema $O$ Cavaleiro de Bronze, de Puchkin, que retrata a cidade de São Petersburgo, à época de uma de suas grandes enchentes, com tons apocalípticos; o conto O projeto Nevski, de Gogol, que representa a Avenida Nevski como palco de encantamentos e decepções; e Memórias do Subsolo, de Fiodor Dostoievski. A última é uma das obras que traz como protagonista um funcionário pobre, um tipo de personagem que aparece pela primeira vez em $O$ Cavaleiro de Bronze, e que se tornará recorrente na literatura do século XIX na Rússia; além disso, apresenta, de forma diferente, "o paradigma clássico de Petersburgo", nas palavras de Berman: "o oficial aristocrático versus o funcionário pobre", uma situação bastante explorada na literatura russa.

\section{A AVENIDA NEVSKI COMO ESPAÇO DA MODERNIDADE EM SÃo PETERSBURGO}

Uma das ruas principais de São Petersburgo, a Avenida Nevski, foi reconstruída no início do século XIX, sendo projetada por arquitetos neoclássicos. No final da década de 1820, era a rua mais longa, mais larga, mais bem pavimentada e iluminada da cidade. Era uma rua que trazia o fascínio da modernidade: lojas de artigos importados móveis, tecidos, livros, roupas -, amplo espaço para as pessoas circularem, vitrines. Assim, a rua se tornou um espaço urbano caracteristicamente moderno:

\footnotetext{
em primeiro lugar, a retidão, a largura, o comprimento e a boa pavimentação fizeram dele [o projeto Nevski] o meio ideal para a locomoção de pessoas e coisas, uma artéria perfeita para os modos emergentes de tráfego rápido e pesado. Como os bulevares que Haussmann abriu por toda Paris na década de 1860, ele serviu como ponto de convergência de forças humanas e material recentemente acumulado: macadame e asfalto, luz a gás e elétrica, a ferrovia, bondes elétricos e automóveis, cinema e demonstração de massa. Mas, porque foi bem planejada e projetada, a Nevksi entrou em ação uma geração antes de suas correlatas parisienses e funcionou bem mais suavemente, sem devastar vidas ou vizinhanças antigas (BERMAN, 2007, p. 228).
}

Os bulevares idealizados por Haussmann, prefeito de Paris à época de Napoleão III, foram assoladores; ao lado das construções, acumulavam-se detritos das casas miseráveis que antes existiram. Bairros pobres e ruas medievais foram inteiramente 
destruídos para dar lugar aos bulevares. Para construir a Avenida Nevski, não houve esse tipo de devastação. Outra particularidade da avenida foi seu cosmopolitismo mesmo no regime extremamente autoritário de Nicolau, ela não foi dominada pelo Estado - e nela todas as classes sociais se reuniam. Mas, se a construção da Nevski foi mais harmoniosa do que a dos bulevares de Haussmann, o mesmo não se pode dizer sobre os encontros entre as diferentes classes sociais.

Na Rússia do século XIX, mesmo com a modernização e a ascensão do capitalismo, ainda imperava um rígido sistema social de castas; os mais pobres tinham de ceder lugar a dignitários, nobres e oficiais. Mesmo sendo um espaço cosmopolita e não dominado pelo Estado, na Nevski ainda predominavam as convenções dessa sociedade de castas. É neste contexto que ocorre o confronto do "oficial de 1,80 metro de altura" versus o "homem do subterrâneo - funcionário pobre". É na Avenida Nevski que o protagonista sai do subterrâneo e vive na prática o confronto com outras pessoas e consigo mesmo, que se defronta, por um lado, com sua extrema vaidade; por outro lado, com sua autoimagem medíocre e repugnante. O homem do subterrâneo vê-se como um homem mau, desprezível, hipocondríaco e, ao mesmo tempo, como dono de um caráter nobre, uma inteligência extrema e uma aguda consciência da situação em que vivem os outros e ele mesmo.

\section{O “PARADOXALISTA” - QUEM É O HOMEM DO SUBTERRÂNEO?}

Considerado por George Steiner (apud SCHNAIDERMAN, 2000, p. 10) como "o mais dostoievskiano dos livros", Memórias do subsolo foi publicado em 1864 e não recebeu atenção da crítica nesta época. Mais tarde, porém, ganhou o status de uma das mais importantes obras da modernidade. Boris Schnaiderman (2000, p. 11) escreve que

\section{a subjetividade agressiva e torturada do narrador-personagem, o seu discurso alucinado e sua veemência desordenada, o fluxo contínuo de sua fala, que parece estar sempre transbordando, pode ser ouvido por detrás da obra de muitos escritores da modernidade.}

$\mathrm{Na}$ primeira parte do livro, composta por onze capítulos, o homem do subterrâneo encontra-se com quarenta anos, solitário e ranzinza. É o momento em que tem lugar um diálogo do protagonista com interlocutores imaginários, e quando o homem do subsolo contrapõe suas ideias às ideologias pregadas no século XIX, materializadas nas vozes dos "senhores" com quem debate. Schnaiderman (ibid., p. 8) observa que o protagonista é o porta-voz no ataque ao racionalismo e à mentalidade positivista; e, embora não sejam definidos quem são os seus interlocutores, "o 'paradoxalista' fica polemizando com autores e opiniões da época".

Ao mesmo tempo, ele está sempre preocupado com a imagem que estes "senhores" têm dele, e por isso, antecipa-lhes a fala: "Dizei-me: de que pode falar um homem decente, com o máximo prazer? Resposta: de si mesmo. Então, também vou falar de mim" (DOSTOIEVSKI, 2000, p. 18). Entre as contradições pelas quais se justifica a autodefinição do protagonista como "paradoxalista", também percebe-se que ele se vê como vil, desprezível, mas encontra prazer na sua decadência:

Remordia-me então em segredo, dilacerava-me, até que o amargor se transformasse, finalmente, em certa doçura vil, maldita, e, depois, num 
prazer sério, decisivo! Sim, num prazer, num prazer! [...] Vou explicar-vos: o prazer provinha justamente da consciência demasiado viva da minha própria degradação; vinha da sensação que experimentava de ter chegado ao derradeiro limite (ibid., p. 20).

O homem do subsolo tem uma consciência aguda de si mesmo; por um lado, sabe que é um sujeito feio, ignóbil, e por isso não se aproxima das outras pessoas; por outro lado, também se considera "inteligente ao extremo", e sente a necessidade de que as pessoas reconheçam nele essa inteligência, admirem-no. Nas ruas e no ambiente de trabalho, ele encontra seus colegas - em seu ponto de vista, todos iguais - só ele é diferente. O protagonista se coloca acima dos outros; mas também, às vezes, coloca-se abaixo deles, não consegue olhá-los nos olhos. Isto o faz sentir-se angustiado e querer isolar-se cada vez mais em seu subterrâneo: "torturava-me então mais uma circunstância: o fato de que ninguém se parecesse comigo e eu não fosse parecido com ninguém". O homem do subsolo recusa-se a se identificar como parte do "rebanho" onde está inserido; despreza os colegas de trabalho, assim como desprezou os colegas de escola, pois não os considera tão inteligentes e conscientes de sua situação quanto ele:

Temia, também, a ponto de adoecer, tornar-me ridículo, e, por isto, adorava como um escravo a rotina em tudo o que se relacionava com coisas exteriores; entregava-me amorosamente à vida cotidiana e comum e do fundo da alma assustava-me ao notar em mim alguma excentricidade. E como poderia deixar de ser assim? Eu era doentiamente cultivado, como deve ser um homem de nossa época. Eles, pelo contrário, eram todos embotados e parecidos entre si, como carneiros de um rebanho. É possível que eu fosse o único em toda a repartição a ter continuamente a impressão de ser um covarde e um escravo, e talvez tivesse esta impressão justamente porque era cultivado (ibid., p. 57).

O protagonista, mesmo com seu caráter amargo e solitário, não é um sujeito mau. Como observa Frank (2002, p. 437): "a natureza do homem do subterrâneo de modo algum é viciada e má [...]. O homem do subterrâneo está enredado num conflito entre os aspectos egoístas do seu caráter e os traços compassivos e expansivos que também possui". É a sua vaidade que o faz desprezar a todos. Porém, ainda de acordo com o autor,

Como quer que essa superioridade seja reconhecida pelos outros, odeia o mundo por causa de sua indiferença e descamba para uma aversão contra si próprio por causa de sua dependência. É essa a dialética psicológica de um egoísmo consciente que procura conquistar o reconhecimento do mundo e, em compensação, apenas suscita desprazer e hostilidade (ibid., p. 458).

No segundo capítulo da primeira parte do romance, há também a antecipação de alguns eventos que serão narrados na segunda parte, eventos que revelam essa natureza contraditória que se satisfaz ao encarar sua própria miséria:

Tenho, por exemplo, um terrível amor-próprio. Sou desconfiado e me ofendo com facilidade, como um corcunda ou um anão, mas, realmente, tive momentos tais que, se me acontecesse receber um bofetão, talvez até me alegrasse com o fato (DOSTOIEVSKI, 2000, p. 20). 
Esta passagem remete a um episódio, narrado na segunda parte do romance, em que o protagonista tenta arranjar briga com um oficial, mas este o ignora. O "terrível amor-próprio" do homem do subterrâneo, que o faz sentir a necessidade de ser reconhecido pelos outros, leva-o a buscar outras formas de chamar a atenção do oficial e até mesmo de enfrentá-lo, mas essas tentativas também fracassam.

Ao final da primeira parte, o homem do subterrâneo, depois de um longo devaneio, resolve contar suas memórias. Frank (2002) identifica dois conflitos principais na vida do personagem: o primeiro, entre a razão e o rancor, é o foco do primeiro segmento do livro; no segundo segmento, tem lugar o conflito entre o egoísmo e o altruísmo, ou a vontade de se relacionar com outras pessoas.

\section{O HOMEM DO SUBTERRÂNEO NA RUA: A AVENIDA NEVKSI COMO PALCO DE ENCONTRO, HUMILHAÇÃO E "VINGANÇA”}

O referido episódio do encontro do oficial com o homem do subterrâneo ocorre na sua juventude. Certa noite, em que sente necessidade de "sair do subsolo" e ir para a rua, presencia uma briga numa taverna. Um oficial atira outro homem pela janela, o protagonista sente inveja deste homem. Isto o leva a entrar na taverna para arranjar briga com o mesmo oficial, pois, embora se arriscando a levar uma surra, ele se sentirá importante, visto que constatará ser digno de chamar a atenção de alguém que ocupa uma posição social superior à sua. Essa tentativa, no entanto, fracassa e se torna uma humilhação para o homem do subterrâneo, pois no momento em que ele se coloca na frente do oficial, este o afasta com a mesma naturalidade que move uma cadeira, um objeto qualquer do lugar:

\footnotetext{
Eu estava em pé junto à mesa de bilhar, estorvava a passagem por inadvertência, e ele precisou passar; tomou-me então pelos ombros, e, silenciosamente, sem qualquer aviso prévio ou explicação, tirou-me do lugar em que estava, colocou-me em outro e passou por ali, como se nem sequer me notasse. Até pancadas eu teria perdoado, mas de modo nenhum poderia perdoar que ele me mudasse de lugar e, positivamente, não me notasse.

O diabo sabe o que não daria eu, naquela ocasião, por uma briga de verdade, mais correta, mais decente, mais - como dizer? - literária! Fui tratado como uma mosca. Aquele oficial era bem alto, e eu sou um homem baixinho, fraco. A briga, aliás, estava em minhas mãos: bastava protestar e, naturalmente, seria posto janela afora. Mas eu mudei de opinião e preferi... apagar-me, enraivecido (DOSTOIEVSKI, 2000, p. 61-62).
}

Para os russos no século XIX, tal confronto é inconcebível devido ao distanciamento entre as castas. Um oficial não duelaria com um funcionário porque, de acordo com as convenções em vigor naquela sociedade, tomar tal atitude implicaria uma concessão de igualdade que significaria rebaixar-se a um nível inferior, pois um funcionário teria uma natureza tão insignificante que nem chegaria a perturbar, porque não se atribui condição de sujeito a um membro de classe mais baixa. A diferença entre as castas é tão grande que o oficial desconsidera uma intencionalidade na atitude do protagonista, desprezando sua provocação.

A posição que ocupa na sociedade permite ao oficial não se importar com o que considera um ser de natureza inferior. Neste sentido, o homem do subterrâneo não tenta novamente provocar o oficial porque lhe falta "coragem moral", ou seja, não tem medo 
de ser espancado, mas de passar por um vexame na frente de "funcionariozinhos". Em outras palavras, cientes do funcionamento de tais normas de conduta e as aceitando incontestavelmente, as pessoas iguais a ele não entenderiam o porquê de sua briga e poderiam ridicularizá-lo:

\footnotetext{
Não me assustei com a altura do oficial, nem com a perspectiva de ser dolorosamente espancado e jogado pela janela; e realmente eu teria coragem física, o que me faltou foi coragem moral. Assustei-me com o fato de que os presentes - desde o insolente rapaz que marcava os pontos até o funcionariozinho apodrecido, rosto coberto de cravos, que se esgueirava por ali de um lado para o outro, o colarinho coberto de gordura - não me compreenderiam e me cobririam de zombarias, quando eu protestasse e passasse a falar-lhes numa linguagem literária. [...] eu estava plenamente convicto (o senso de realidade, apesar de todo o romantismo!) de que todos eles iriam simplesmente rebentar de rir (DOSTOIEVSKI, 2000, p. 64).
}

Nesta passagem, nota-se que o protagonista mostra indignação com relação à indiferença do oficial, porém não tem coragem de enfrentá-lo porque, no fundo, reconhece o ridículo de sua situação: um funcionário, pobre, mal vestido, baixinho, desafiando um oficial alto e forte. Os homens presentes no momento estão mais próximos socialmente do homem do subterrâneo do que do oficial, mas isso não significa que o apoiariam em tal conflito.

Encarando a situação de uma forma mais idealizada, mais 'literária' - o "romantismo" a que o protagonista se refere - lutar com o oficial, mesmo perdendo, seria um admirável ato de coragem, uma reivindicação da dignidade dos membros das classes mais baixas. Entretanto, devido a um padrão de comportamento imposto pela sociedade de castas e assimilado pelas pessoas, aqueles sujeitos encaravam como normal um homem de uma casta superior tratar um funcionário como um objeto qualquer, de modo que, naquele contexto, tal enfrentamento seria absurdo, chegando mesmo a ser considerado ridículo. Consciente disso, o protagonista - com seu "senso de realidade" -, desiste de desafiar o oficial naquele lugar.

No entanto, essa ideia não o abandona, pelo contrário, transforma-se numa obsessão. O homem do subsolo pensa em várias formas de provocar o oficial, segue-o nas ruas, descobre onde ele mora. A primeira vingança que tenta realizar é a elaboração de uma novela em que satiriza a figura do oficial; escreve-a, mas não consegue publicála. Depois, pensa em desafiar o oficial para um duelo. Para isso, escreve-lhe uma carta, mas se convence de que o oficial jamais aceitaria duelar com um civil de casta inferior, e desiste de enviá-la. Nesta, há uma intenção além do duelo: o homem do subterrâneo quer ser reconhecido, admirado pelo oficial. Em seu devaneio, chega a cogitar sua amizade. Como afirma Berman (2007, p. 261), “detrás da mensagem de ira e rancor transparece um subtexto que transpira um anseio abjeto pelo amor do inimigo". A carta, "linda e atraente", foi escrita para atrair a atenção do oficial:

A carta foi escrita de modo que, se o oficial compreendesse um pouco sequer o "belo e sublime", seguramente viria correndo à minha casa, para se atirar ao meu pescoço e oferecer a sua amizade. E como seria bom! Viveríamos tão bem, como amigos! Tão bem! Ele me defenderia com a imponência de sua posição; eu o tornaria mais nobre com a minha cultura, bem... com as idéias também, e muita coisa poderia acontecer! (DOSTOIEVSKI, 2000, p. 65). 
Analisando essa atitude do protagonista, pode-se perceber que seu anseio por enfrentar o oficial não representa uma questão de reivindicar igualdade de classes. $\mathrm{O}$ homem do subterrâneo considera-se digno de ser reconhecido pelo oficial não porque, além de ser 'funcionário', é um ser humano, não porque pregue ideais de igualdade de condições entre os homens, mas porque, apesar de ser um mero funcionário, ele deve ser tratado como um homem respeitável por ser culto e inteligente. Sua luta não é para representar uma classe, é um anseio, mais estritamente pessoal, de ser admirado, e não exatamente uma reivindicação por mudanças nas convenções, no estado de coisas do meio social onde vive.

Assim como saiu profundamente humilhado da taverna onde encontrou o oficial, o homem do subterrâneo sentia-se humilhado ao andar pela rua, ao voltar para sua rotina. Mesmo assim, sente-se atraído pela rua: este lugar possibilita-lhe encontrar a multidão, aproximar-se das pessoas, todavia, revela de modo doloroso a sua condição na sociedade:

\begin{abstract}
Às vezes, nos dias feriados eu ia, depois das três, para a Avenida Nevski e ficava passeando ao lado do sol, isto é, não passeava absolutamente, mas experimentava sofrimentos sem conta, humilhações e derrames de bílis; mas é provável que precisasse justamente disso. Esgueirava-me, como uma enguia, do modo mais feio, por entre os transeuntes, cedendo incessantemente caminho ora a generais, a oficiais da cavalaria ou dos hussardos, ora a senhoras; sentia, nesses momentos, dores convulsivas no meu coração e calor nas espáduas, à simples idéia da miséria do meu traje e da vulgaridade da minha deslizante figurinha. Era o cúmulo do suplício, uma humilhação incessante e insuportável, suscitada pelo pensamento, que se transformava numa sensação contínua e direta de que eu era uma mosca perante todo aquele mundo, mosca vil e desnecessária, mais inteligente, mais culta e mais nobre que todos os demais, está claro, mas uma mosca cedendo sem parar diante de todos, por todos humilhada e por todos ofendida. Para que recolhia em mim tal sofrimento, não sei; mas algo me arrastava para lá sempre que era possível (DOSTOIEVSKI, 2000, p. 66).
\end{abstract}

Nesta passagem, evidencia-se o que significa para o homem do subterrâneo a Avenida Nevski: um lugar atraente - algo o "arrastava" para lá -, mas também um lugar onde ficava clara a sua insignificância - tinha de ceder lugar para todos, caminhava esgueirando-se na multidão, sentia-se reduzido a um inseto. Como afirma Berman (2007, p. 263), o projeto Nevski "é um moderno espaço público que oferece uma fascinante promessa de liberdade; e, no momento, para o funcionário pobre da rua, as configurações de casta da Rússia feudal são mais rígidas e humilhantes do que nunca". A Avenida Nevski carregava o paradoxo de ser um lugar moderno, onde as pessoas de todas as classes teriam liberdade e igualdade de condições de circular; porém, ao mesmo tempo em que se propunha ser um lugar público, ainda vigoravam as leis da sociedade de castas, leis que a modernidade ainda não tivera forças para modificar. Portanto, a rua revela-se um lugar das contradições que abalam a vida do personagem, pois o lugar que seria o palco de sua afirmação como sujeito, o lugar em que ele se exporia e entraria em contato com outras pessoas, acaba se tornando um meio que o faz se sentir 'apagado' perante estas pessoas. A liberdade que a avenida prometia converte-se, na prática, em opressão e sofrimento.

Na Avenida Nevski, o protagonista também encontrava frequentemente o oficial e sempre lhe cedia espaço para passar. Isso foi aumentando ainda mais sua raiva e evidenciando ainda mais sua impotência: 
Também ele ia à avenida, sobretudo nos dias feriados. Embora também se desviasse ante os generais e outras pessoas de alta posição, e também se esgueirasse por entre eles como uma enguia, quando se tratava de pessoas da nossa espécie, ou mesmo um pouco melhor, ele simplesmente as pisava; ia na sua direção como se tivesse diante de si um espaço vazio, e jamais cedia caminho. Olhando-o eu me embriagava com a minha raiva, mas... cheio de raiva, cada vez me desviava dele. Atormentava-me o fato de que, mesmo na rua, não pudesse tratá-lo de igual para igual (DOSTOIEVSKI, 2000, p. 667).

A rua é um lugar aberto, caracterizado pela possibilidade de exposição e manifestação. Entretanto, apresenta um caráter que leva o indivíduo à introversão. A raiva do protagonista relaciona-se com o fato de a rua mostrar-lhe sua condição insuperável. Um dia, entretanto, ao caminhar pela avenida, tem uma ideia que, naquela situação, seria extremamente ousada: "E eis que de chofre um pensamento muito surpreendente tomou conta de mim: 'e que tal', pensei, 'que tal se me encontrar com ele e... não ceder passagem?'” (ibid., p. 67). Esta ideia é impulsionada pelo fato de que o oficial, mesmo com todo o seu poder e arrogância, não é um homem "acima da lei". Ele "pisa" em pessoas da casta mais baixa, porém, assim como estas, ele também está sujeito a ser obrigado a ceder passagem, a esgueirar-se entre aqueles que estão em um nível hierárquico superior. Portanto, o oficial é um ser humano sujeito às normas sociais tanto quanto o protagonista, o que lhe anima a seguir com seu plano.

Obstinado com o plano de passar pelo oficial sem se desviar, o homem do subterrâneo passa a ir com mais frequência à avenida para procurar o oficial e imaginar como colocará sua ideia em prática. Para poder enfrentar o oficial em igualdade de condições, chega até a comprar boas roupas, para estar bem apresentado no "grande encontro". Planeja minuciosamente, todavia, cada vez que volta à avenida, ou não vê o oficial, ou, encontrando-o, não tem coragem de colidir com ele e acaba cedendo caminho mais uma vez. A agonia do personagem chega a tal ponto que ele, em uma das vezes que vê o seu "inimigo", toma coragem para esbarrar nele. Contudo, no último instante, cai aos pés do oficial, que continuava alheio a todas as investidas do homem do subsolo: "ele caminhou por cima de mim com toda a tranqüilidade, e eu me atirei para um lado, como uma bola" (DOSTOIEVSKI, 2000, p. 69). Com várias tentativas malogradas, o protagonista desiste do seu plano. Porém, no dia seguinte, caminhando na Nevski, reencontra o oficial e, de repente,

a três passos do meu inimigo, inesperadamente me decidi, franzi o sobrolho e... chocamo-nos com força, ombro a ombro! Não cedi nem um vierchók e passei por ele, absolutamente de igual para igual! Ele não se voltou sequer e fingiu não ter visto nada; mas apenas fingiu, estou certo. Guardo essa convicção até hoje! Está claro que sofri o golpe mais violento; ele era mais forte. Mas não era isso que importava. O que importava era que eu atingira o objetivo, mantivera a dignidade, não cedera nem um passo, e, publicamente, me colocara ao nível dele, do ponto de vista social. Voltei para casa vingado de tudo. Meu estado era de arrebatamento. Triunfara, e ia cantando árias italianas. [...] O oficial foi depois transferido não sei para onde, já faz uns quatorze anos que não o vejo. Por onde andará agora o meu caro amigo? Em quem estará pisando? (ibid., p. 70).

Neste momento, a rua, que até então tinha sido palco de humilhações e sofrimentos para o protagonista, torna-se o lugar de sua glória. O choque pode não ter 
tido resultado concreto nenhum, porém, para o personagem, isso basta para pôr termo a seu conflito interior, à ideia fixa de que, ao conseguir passar pelo oficial sem se desviar, ele superaria sua necessidade de afirmação. Berman, ao analisar esta passagem do romance, afirma:

\begin{abstract}
Ele conseguiu: arriscou corpo e alma, enfrentou a casta dominante, insistiu na sua igualdade de direitos, e [...] proclamou-a diante do mundo todo. [...] ao lutar, à luz do dia, por sua liberdade e dignidade, ao lutar apenas contra o oficial, mas também contra a desconfiança e o ódio que nutre contra si mesmo, o Homem do Subterrâneo venceu. [...] as classes mais baixas estão aprendendo a pensar e andar de um modo novo, a afirmar uma nova presença e poder na rua. Não importa que a alta e a baixa nobrezas não tenham ainda percebido; serão obrigadas a perceber logo. [...] ele agiu decisivamente para mudar a sua vida, e nenhuma autonegação ou falha subseqüente poderá fazê-lo voltar ao que era. Ele se tornou um Homem Novo, quer queira, quer não (BERMAN, 2007, p. 267).
\end{abstract}

Entretanto, Berman pondera: "como se trata de Dostoiesvski, há múltiplas possibilidades de interpretação". A repetição do protagonista de que ele está certo de que o oficial fingiu não tê-lo visto sugere que ele não está tão certo quanto gostaria, e o fato de a novela ser narrada em primeira pessoa, não havendo um narrador onisciente, implica uma perspectiva limitada à experiência e às possibilidades de compreensão do indivíduo que narra. Por isso, não é possível ter certeza de que o outro apenas fingiu não ver o homem do subsolo. Tal incerteza, ligada ao ponto de vista do personagem, implica que os acontecimentos em questão referem-se menos a verdades gerais, de alcance social, do que a caprichos de um homem extremamente vaidoso. A afirmação de Berman de que o protagonista se tornou um "homem novo" também é questionável, afinal, o caráter de um "homem novo" não causaria uma impressão tão insignificante para os antigos colegas de escola, como acontece posteriormente na narrativa:

Encontrei ali mais dois colegas de escola. Pareciam tratar de um caso importante. Nenhum deles notou a minha chegada, o que era estranho até, pois fazia anos que não nos víamos. Provavelmente, consideravam-me algo semelhante à mais ordinária das moscas. Nem mesmo na escola me haviam tratado daquele modo, embora todos me odiassem lá. Compreendia, naturalmente, que deviam desprezar-me pelo fracasso de minha carreira de funcionário e pelo fato de eu ter decaído muito, de andar mal trajado, etc. (DOSTOIEVSKI, 2000, p. 75).

Se houvesse uma renovação na sua autoimagem e na sua essência social, haveria uma dignidade no protagonista que seria percebida e apreciada pelos demais, que passariam a respeitá-lo; no entanto, não é o que ocorre. Assim, passado o incidente na Avenida Nevski, o protagonista volta à sua rotina, com o mesmo comportamento de antes: continua a ser uma 'enguia' na multidão. Continua a ter uma imagem negativa de si mesmo e imagina que os outros também o veem dessa forma.

\footnotetext{
${ }^{1} \mathrm{O}$ termo "homem novo" refere-se a uma nova geração de cidadãos russos - os raznochintsy, intelectuais que não eram oriundos das classes nobres - que começou a surgir na década de 1860, com o reinado de Alexandre II, período em que houve transformações radicais na cultura russa, tais como a libertação dos servos. Os "homens novos" questionam as instituições, as convenções sociais e, na década de 1870, realizam manifestações políticas, algo totalmente novo na Rússia do século XIX.
} 
Além disso, a indagação "por onde andará agora o meu caro amigo? Em quem estará pisando?" sugere que o comportamento do oficial segue sendo igual, que ele continua ignorando e oprimindo os membros das castas inferiores, mesmo tendo decorrido tanto tempo desde o referido incidente; ou seja, o choque não provocou nenhuma mudança social ou ideológica para o oficial. Isso demonstra a nulidade, no sentido sociológico, do ato do protagonista - o dêitico agora remete ao tempo do discurso, ou seja, ao tempo em que o homem do subsolo, com quarenta anos, rememora este acontecimento que ocorreu em sua juventude. Assim, a afirmação de Berman de que as classes mais altas perceberão a nova presença dos membros das classes baixas é correta se considerar-se a história posterior da Rússia, porém, ainda não se aplica àquela realidade que está sendo representada em Memórias do subsolo.

Berman acentua as implicações sociais e ideológicas desse encontro entre o protagonista e o oficial, sem considerar que, na narrativa, essas implicações não são a maior preocupação do narrador-protagonista, sendo secundárias do ponto de vista da organização ficcional deste romance. Também não atenta para o fato de que o tempo das ações narradas remonta à década de 1840, ou seja, ainda não ocorreram os eventos que possibilitariam, na sociedade russa, o surgimento de um "homem novo", que luta por igualdade e questiona o sistema social.

Frank (2002, p. 461) analisa o "encontrão" do homem do subsolo sob outro viés. Para este autor,

Todos esses episódios mostram os tormentos e torturas do homem do subterrâneo quando tenta afirmar sua existência como um ego que deseja, acima de tudo, que alguém - qualquer um - reconheça seu direito a ser aceito de maneira compatível com sua auto-imagem absurdamente inflada. É por esta razão que se envolve na farsa burlesca, herói-cômica, de tentar armar-se de bastante coragem para dar um encontrão num oficial na Avenida Nevksi. Sua preocupação com esse ridículo problema apenas ilustra o caráter insignificante e obsessivo de sua vaidade; mas o episódio é também uma paródia de um incidente narrado em Que fazer? Um dos heróis desse livro toma a solene resolução de não ceder o direito de passagem na rua aos "dignitários"; e, quando um cavalheiro ultrajado começa a repreender o estudante mal-vestido por ter colidido com ele, o dignitário acaba caindo de rosto na lama.

Invertendo, ironicamente, a escala de valores manifestada por este processo democrático contra as humilhações públicas da desigualdade, Dostoievski descreve o desejo frenético do homem do subterrâneo de afirmar sua "igualdade" mais como uma cômica vaidade do que como um auto-respeito solidamente independente.

Levando-se em consideração o caráter literário da obra, a interpretação de Frank parece ser mais pertinente do que a de Berman em alguns aspectos, pois mostra que a necessidade de enfrentar o oficial - que Berman interpreta como uma luta por direitos humanos - é, na verdade, uma ilusão de que, ao realizar a façanha de enfrentar o oficial, ele estaria provando para si mesmo sua dignidade e, com isso, elevando sua autoestima. No momento em que ele consegue tal proeza, o acontecimento torna-se passado, perdendo o interesse. Por isso, não opera uma mudança no caráter do personagem.

Frank também identifica a relação que existe entre Memórias do subsolo e Que fazer $?^{2}$, romance que apresenta como protagonista um jovem estudante que representa $\mathrm{o}$

\footnotetext{
${ }^{2}$ Romance de Tchernichévski, publicado em 1863, um ano antes de Memórias do Subsolo.
} 
modelo de "homem novo", que desafia as normas impostas pela sociedade de castas. Enquanto Berman apenas afirma que há alusões à obra de Tchernichévski, e aponta as diferenças e as semelhanças que existem entre os dois romances ${ }^{3}$, Frank estabelece o tipo de relação que há entre uma obra e outra: a paródia, que é realizada por Dostoievski, neste caso, invertendo o sentido que esse episódio tinha no contexto original (FRANK, 2002, p. 431).

No romance de Tchernichévski, o estudante enfrenta o dignitário corajosamente, de modo que a cena tem um caráter heróico, ao passo que, em Memórias do subsolo, o protagonista tenta várias vezes realizar este tipo de proeza, e, em uma delas, sua luta adquire um caráter cômico: um homem baixo, pretensioso, arma-se de coragem, faz "pose" de homem forte, aproxima-se do inimigo e... Acaba caindo no chão. Tal comicidade não teria sentido em um romance que, assim como Que fazer?, tivesse a intenção de glorificar aqueles que desafiam as normas sociais. Entende-se, deste modo, que a novela de Dostoievski pode ser considerada uma paródia da obra de Tchernichévski, na qual faz sentido a ideia de que o desejo de se confrontar com o oficial tende mais para uma vaidade cômica e fútil do que para um ato revolucionário, pois o homem do subterrâneo assinala com frequência o seu caráter vaidoso no decorrer da narrativa:

Atualmente, percebo, com toda a nitidez, que eu mesmo, em virtude da minha ilimitada vaidade e, por conseguinte, da exigência em relação a mim mesmo, olhava-me com muita freqüência, com enfurecida insatisfação que chegava à repugnância e, por isso, atribuía mentalmente a cada um o meu próprio olhar (DOSTOIEVSKI, 2000, p. 56).

A insignificância de suas preocupações pode ser percebida, por exemplo, quando o protagonista pensa sobre quais luvas comprar para usar no dia do choque com o oficial. Em dúvida se compra luvas pretas ou cor de limão, acaba convencendo-se de que as pretas seriam mais adequadas por serem menos chamativas (ibid., p. 68). Sobre a vaidade do personagem, Frank (2002, p. 458-9) destaca:

A vaidade do homem do subterrâneo convence-o da sua própria superioridade e ele despreza a todos; mas, como quer que essa superioridade seja reconhecida pelos outros, odeia o mundo por causa de sua indiferença e descamba para uma aversão contra si próprio por causa da sua humilhante dependência. [...] Além de descrever essa dialética da vaidade em ação, Dostoievski também atribui sua origem a uma fonte ideológica - não a uma doutrina filosófica específica como na parte I, mas à atmosfera cultural geral dos anos 1840, que favorecia um egoísmo romântico forçado e artificial e um sentimento de superioridade à vida dos russos comuns que o homem do subterrâneo absorveu por todos os poros.

Berman considera o "encontrão" na Avenida Nevski como algo revolucionário, "que dramatiza tão poderosamente a luta pelos direitos humanos" (2007, p. 267). Frank interpreta esse acontecimento como algo cômico e caricato, e está mais atento ao caráter do personagem e seu comportamento ao longo da narrativa, ou seja, a elementos

\footnotetext{
${ }^{3}$ Com relação a Memórias do subsolo e Que fazer?, Berman (2007, p. 259) observa: "sua diferença radical para com a cena de Chernychevski reside no fato de que são necessários vários anos de angústia exaustiva para o Homem do Subterrâneo desafiar a autoridade, que se desdobra em oitenta páginas intensa e densamente escritas. Sua semelhança [...] reside no fato de que ela ocorre: após uma agonia introspectiva hamletiana aparentemente interminável, o Homem do Subterrâneo finalmente age”.
} 
intrínsecos do romance. A análise de Berman é mais voltada para a relação entre o universo ficcional e a realidade da época em que o romance foi escrito e acentua o aspecto ideológico de um confronto entre um funcionário pobre e um membro da casta mais elevada; porém, pode-se verificar que as implicações ideológicas desse fato não têm a mesma ênfase na narrativa.

Entretanto, se por um lado a análise de Marshall Berman enfatiza um aspecto que não é o mais destacado na novela, por outro lado, são bastante perspicazes suas observações acerca do espaço em que o confronto do homem do subterrâneo acontece, a Avenida Nevski:

\begin{abstract}
A Nevski é uma espécie de cenário, deslumbrando a população com artigos rutilantes, quase todos importados do Ocidente, mas ocultando uma perigosa falta de profundidade por detrás da fachada brilhante. A alta e a baixa nobreza ainda desempenham os papéis principais nessa capital imperial (BERMAN, 2007, p. 269).
\end{abstract}

Como Berman aponta, só na década de 1870, muitos anos depois do embate entre o homem do subterrâneo e o oficial, é que as classes mais baixas começarão a se manifestar, e essas manifestações ocorrerão também na Avenida Nevski. Por isso, o romance Memórias do subsolo prefigura a importância que a rua, como espaço público, está começando a conquistar na sociedade moderna: um espaço onde sujeitos de diferentes origens e classes sociais irão se encontrar, se confrontar, e, com isso, os sujeitos oriundos das classes mais baixas começam a ter um espaço para agir e se manifestar, afirmar sua individualidade e sua condição de ser humano, ainda que, no caso do referido romance, isso seja representado de forma mais burlesca, mais satírica. A obra em questão tem este apelo mais voltado para o cômico e para o satírico do que o caráter crítico de denúncia das desigualdades sociais.

Portanto, a Avenida Nevski em Memórias do subsolo pode ser entendida como a representação de um espaço que encerra as contradições da modernidade, particularmente as contradições peculiares da Rússia: encarna as promessas de liberdade e igualdade ao mesmo tempo em que desvela a ideologia de um rígido sistema social que ainda prevalecia, submetendo seres humanos a apagarem sua individualidade em função de sua posição nas castas. Tal contradição foi sentida pelo Homem do subterrâneo, de uma forma que pode ser interpretada como ridícula ou revolucionária, mas, de qualquer modo, intensa.

\title{
REFERÊNCIAS
}

BENJAMIN, Walter. Charles Baudelaire: um lírico no auge do capitalismo. Tradução de José Carlos Martins Barbosa e Hemerson Alves Baptista. São Paulo: Brasiliense, 1989. Obras escolhidas. Vol. 3.

BERMAN, Marshall. Tudo que é sólido desmancha no ar. Tradução de Carlos Felipe Moisés e Ana Maria Ioratti. São Paulo: Companhia das Letras, 2007.

BRADBURY, Malcolm. O mundo moderno. Dez grandes escritores. Tradução de Paulo Henriques Britto. São Paulo: Companhia das Letras, 1989.

DOSTOIEVSKI, Fiodor. Memórias do Subsolo. Tradução de Boris Schnaiderman. São Paulo: Editora 34, 2000. 
FRANK, Joseph. Dostoievski: Os efeitos da libertação (1860-1865). Tradução de Geraldo Gerson de Souza. São Paulo: Editora da Universidade de São Paulo, 2002.

SCHNAIDERMAN, Boris. Prefácio. In: DOSTOIEVSKI, Fiodor. Memórias do Subsolo. São Paulo: Editora 34, 2000. 